\title{
Biophysical mechanisms of larval fish ingress into Chesapeake Bay
}

\author{
Jonathan A. Hare ${ }^{1,4, *}$, Simon Thorrold ${ }^{2,5}$, Harvey Walsh ${ }^{1}$, Christian Reiss $^{2,6}$, \\ Arnoldo Valle-Levinson ${ }^{3,7}$, Cynthia Jones ${ }^{2}$ \\ ${ }^{1}$ NOAA NOS NCCOS Center for Coastal Fisheries and Habitat Research, 101 Pivers Island Road, Beaufort, \\ North Carolina 28516, USA \\ ${ }^{2}$ Center of Quantitative Fisheries Ecology, 800 West 46th Street, Old Dominion University, Norfolk, Virginia 23529-0266, USA \\ ${ }^{3}$ Center for Coastal Physical Oceanography, Old Dominion University, 768 West 52nd Street, Norfolk, Virginia 23529, USA \\ ${ }^{4}$ Present address: NOAA NMFS NEFSC Narragansett Laboratory, 28 Tarzwell Drive, Narragansett, Rhode Island 02882, USA \\ ${ }^{5}$ Present address: Biology Department, Woods Hole Oceanographic Institution, Woods Hole, Massachusetts 02543, USA \\ ${ }^{6}$ Present address: NOAA NMFS Southwest Fisheries Science Center, 8604 La Jolla Shores Drive, La Jolla, \\ California 92037-1508, USA \\ ${ }^{7}$ Present address: Civil and Coastal Engineering, 365 Weil Hall, Box 116580, Gainesville, Florida 32611, USA
}

\begin{abstract}
Selective tidal stream transport is hypothesized as a dominant mechanism by which larvae of marine animals move through estuarine openings. For larvae moving from the shelf to estuarine habitats, selective tidal stream transport proposes that larvae are higher in the water column during flood tide and lower in the water column during ebb tide. Although a number of studies conclude that selective tidal stream transport is the mechanism responsible for larval ingress, few studies consider alternative mechanisms or consider passive explanations for tidal patterns in larval distributions. We examined the biophysical mechanisms responsible for larval ingress into Chesapeake Bay using an Eulerian approach. We made flux calculations for 3 species and partitioned flux estimates among 3 different ingress mechanisms (wind forcing, residual bottom inflow and tidal). For the Atlantic croaker Micropogonias undulatus (Sciaenidae), all 3 mechanisms of ingress contributed to the net up-estuary flux of larvae, but tidal mechanisms become more important for larger sizes. Net up-estuary flux of the Atlantic menhaden Brevoortia tyrannus (Clupeidae) was dominated by residual bottom inflow and wind forcing. Ingress of the summer flounder Paralichthys dentatus (Paralichthyidae) was dominated by tidal mechanisms, and the importance of tides increased with developmental stage. We found little evidence for the hypothesis that tidal patterns in larval distributions resulted from passive processes (water mass-specific distributions, buoyancy, vertical mixing), thereby supporting the hypothesis that tidal patterns resulted from active behaviors. However, our estimates of vertical mixing were not direct and additional work is needed to examine the role of vertical mixing in influencing vertical distributions in areas with strong tides. We conclude that a combination of wind forcing, residual bottom inflow, and selective tidal stream transport are responsible for the ingress of larval fishes into Chesapeake Bay, and that the relative importance of the 3 mechanisms differs among species and changes with larval development.
\end{abstract}

KEY WORDS: Selective tidal stream transport - Estuarine circulation - Wind-induced exchange • Larval ingress $\cdot$ Recruitment · Larval fishes

\section{INTRODUCTION}

The current paradigm for larval ingress holds that behavior in synchrony with the tides is responsible for movement from the continental shelf into estuarine habitats (see review by Forward \& Tankersley 2001).
Such tidal behaviors, commonly termed 'selective tidal stream transport', are expressed as larvae moving higher in the water column on flood tides and lower in the water column, or to the bottom, on ebb tides, resulting in up-estuary transport. Similar tidal behaviors (also termed selective tidal stream transport) that 
result in down-estuary transport or no net movement have been described for larvae leaving estuaries or retained in estuaries, respectively (Cronin 1982, Dittel \& Epifanio 1990, Rowe \& Epifanio 1994a,b).

Although selective tidal stream transport is widely accepted as the mechanism by which larvae move into estuaries, other mechanisms have been proposed, but are rarely evaluated in combination with the investigation of selective tidal stream transport. In most estuaries, the general pattern of circulation is surface outflow and bottom inflow (Dyer 1997). Late-larvae in the bottom layer can move up-estuary in the residual bottom inflow (Weinstein et al. 1980, Schultz et al. 2003). Eventscale processes may also result in ingress. For example, winds can force water out of an estuary followed by a 'refilling' caused by a gradient in sea surface height (e.g. a barotropic response, Valle-Levinson et al. 1998, 2001). This 'refilling' can result in the movement of larvae into an estuary (see Shaw et al. 1985). The general conclusion that selective tidal stream transport is responsible for larval ingress is weakened if alternative mechanisms are not considered.

When tidal patterns in larval abundance or vertical distribution are documented, the default conclusion is often that behavior is the cause. However, larval distributions in estuarine systems are potentially affected by several physical factors that vary with tides. Larvae are often associated with specific water masses (Cowen et al. 1993, Hare et al. 2001), and accounting for water mass differences in larval abundance is important for identifying the roles of different processes affecting larval abundance in estuaries (Fortier \& Leggett 1985). Tidal patterns in larval distributions could be explained by tidal patterns in the vertical and horizontal distribution of water masses (Norcross 1991). Larval buoyancy may generate tidal patterns in larval distributions (sensu Sclafani et al. 1993, Boehlert \& Mundy 1994), with larvae shallower in the water column at higher water densities and deeper in the water column at lower water densities. Tidal patterns in vertical mixing (see Chant \& Stoner 2001) may also influence the distribution of larvae (Fortier \& Leggett 1983, Henri et al. 1985, Bergman et al. 1989). Passive explanations need to be tested and rejected to make the inference that tidal patterns in larval distribution result from active behavior.

Larval ingress into Chesapeake Bay has been extensively studied. Harrison et al. (1967) concluded that larvae of Atlantic menhaden Brevoortia tyrannus enter the Bay in residual bottom inflow. A similar conclusion was reached by Norcross (1991) for Atlantic croaker Micropogonias undulatus, with the addition that observed changes in vertical distribution could be explained by changes in the vertical structure of water mass distributions rather than behavior. Further, Reiss \& McConaugha (1999) proposed that dynamics of the Chesapeake Bay plume are involved in the entry of Atlantic croaker into the bay. Blue crab Callinectes sapidus ingress has also been examined and several mechanisms have been proposed: wind forcing, residual bottom inflow, passive ingress via tidal processes, and selective tidal stream transport (e.g. Johnson \& Hess 1990, Johnson 1995, Olmi 1995, Roman \& Boicourt 1999). These studies suggest a plurality of mechanisms causing the ingress of larvae into Chesapeake Bay, which conflicts with the growing dogma that selective tidal stream transport is the dominant mechanism by which larvae enter estuarine systems.

Our purpose was to examine the biophysical mechanisms responsible for larval ingress into Chesapeake Bay. Our approach was Eulerian (e.g. over time at a fixed point in space). A variety of factors that could affect larval distributions were measured at 1 location in the Bay mouth, and 2 specific objectives were then addressed: (1) The flux of larvae into Chesapeake Bay resulting from wind forcing, residual bottom inflow, and tidal forcing was quantified; (2) specific physical factors that could cause covariation between larval concentration and the tidal flow field were evaluated. If the hypotheses that physical factors create tidal patterns in larval distributions can be rejected, larval behavior, and by extension selective tidal stream transport, as an alternative hypothesis for tidal patterns is supported.

\section{MATERIALS AND METHODS}

Study area. Chesapeake Bay is representative of wide, partially mixed, coastal plain estuaries (ValleLevinson et al. 1998, 2001). In cross-section, the Bay mouth consists of 2 channels separated by shoals (Fig.1); the North Channel is the shallower of the 2 ( 13 m deep). Both channels are characterized by classic gravitational circulation (net outflow at the surface and net inflow at depth) modified by wind and water discharge (Valle-Levinson et al. 1998, 2001). Semidiurnal constituents $\left(\mathrm{M}_{2}, \mathrm{~N}_{2}\right.$ and $\left.\mathrm{S}_{2}\right)$ dominate tidal forcing and create fortnightly and monthly variability in tidal currents (Valle-Levinson et al. 1998, 2001). Similar to many estuaries along the east coast of the United States (see Münchow et al. 1992, Churchill et al. 1999, Kincaid et al. 2003), buoyant outflows dominate the subtidal flow on the south and west side of the mouth of Chesapeake Bay and subtidal inflows occur on the north and east side of the mouth (ValleLevinson et al. 1998, 2001). An anchor station was occupied in the North Channel of Chesapeake Bay (Fig. 1B) where subtidal inflows occur. Sampling was 

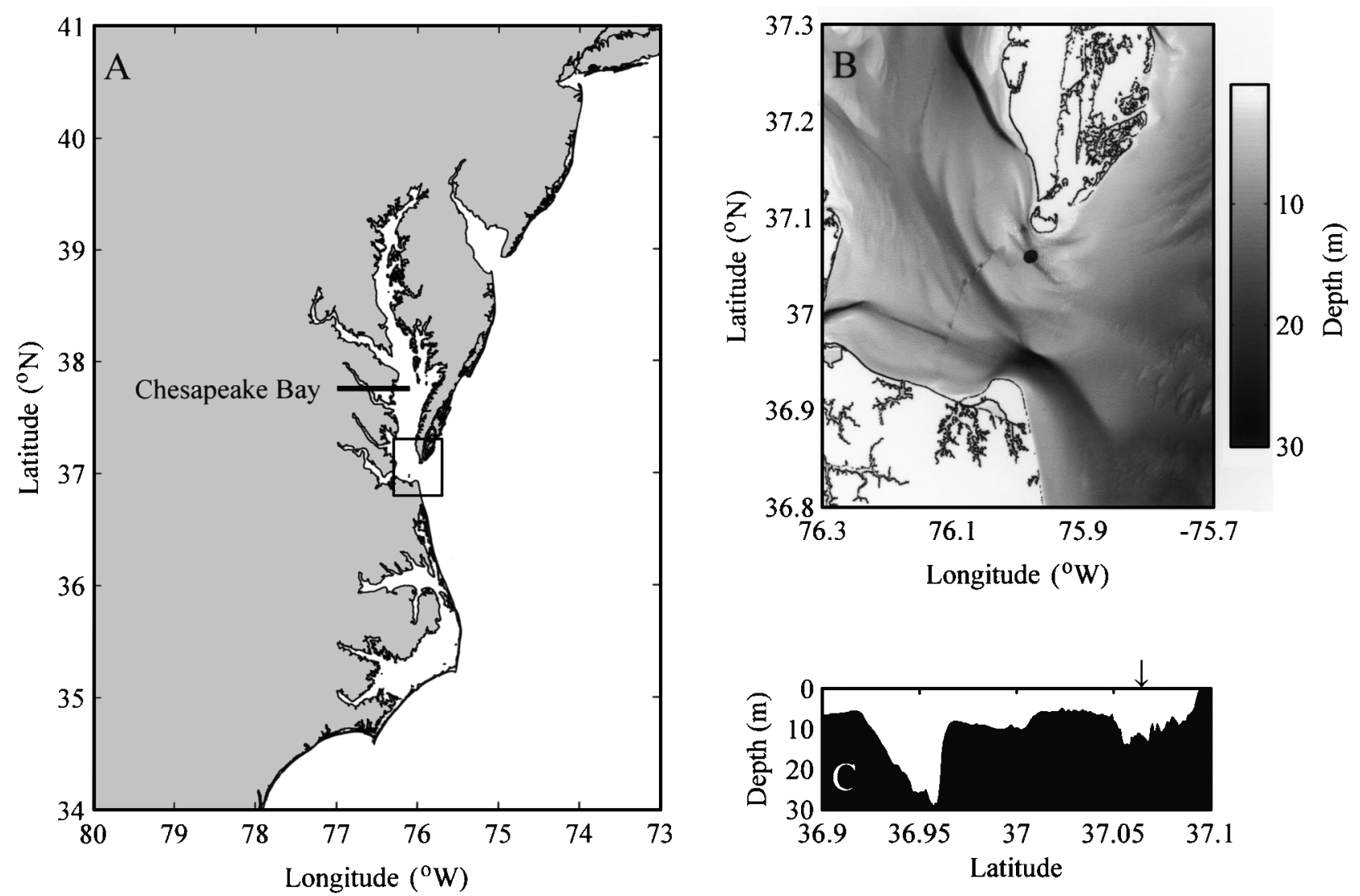

Fig. 1. (A) Study area, showing location of Chesapeake Bay on mid-Atlantic coast of United States; (B) planar view of bathymetry in the region of Chesapeake Bay mouth; $(\mathrm{C})$ cross-section of bay mouth bathymetry. Black circle in planar view and arrow on cross-section indicate location of anchor station

conducted from the NOAA ship Ferrel, between 23:00 h GMT on 16 November and 12:00 h GMT on 19 November 1999. This study was conducted during neap tide conditions.

Physical field sampling. A SeaBird conductivitytemperature-depth (CTD) instrument was deployed at 6 and 36 min past every hour. The CTD malfunctioned between 15:36 h GMT on 17 November and 01:06 h GMT on 18 November ( $\mathrm{n}=20$ casts). In addition, CTD casts were suspended between 13:06 and 17:06 h GMT on 18 November to retrieve a nearby current meter mooring ( $\mathrm{n}=9$ casts).

A downward facing RD Instrument, $612.2 \mathrm{kHz}$ broadband, Acoustic Doppler Current Profiler (ADCP) was deployed off the side of the ship from a raft (see Valle-Levinson et al. 1998). We averaged $4 \mathrm{~s}$ pings over $10 \mathrm{~min}$ ensembles and into $0.5 \mathrm{~m}$ depth bins. Ensembles were further averaged into $30 \mathrm{~min}$ bins to coincide with CTD sampling frequency. The axis of major variance in the flow field was $2^{\circ}$ off of the E-W direction, so E-W flow was defined as down-estuary and upestuary respectively. ADCP data collection was suspended during mooring retrieval.
Biological sampling. Fishes were collected with 3 channel nets attached to a cable deployed from the stern of the ship. Nets were $1 \mathrm{~m}^{2}$, with $950 \mu \mathrm{m}$ mesh, and were located $11.5,7.5$ and $3.5 \mathrm{~m}$ below the surface. All larvae were preserved in $95 \%$ ethanol. Volume filtered was calculated using flowmeters (General Oceanic Model 2030 with low speed rotors) in the mouth of each net. Nets were retrieved and changed on the hour; $7 \mathrm{~h}$ into sampling, 1 of the two $7.5 \mathrm{~m}$ nets was lost, and for the remainder of the sampling period, a $7.5 \mathrm{~m}$ sample was collected only every $2 \mathrm{~h}$. Data for the missing $7.5 \mathrm{~m}$ net $\left(C_{7.5, t}\right)$ were interpolated as the average of $C_{3.5, t}, C_{11.5, t}, C_{7.5, t-1}, C_{7.5, t+1}$, where $t$ is the time of the missing net and $C_{z}$ is larval concentration at depth $z$. Several other, more complex, interpolation methods were evaluated but all methods provided similar overall estimates of larval concentrations and the interpolation method used did not affect the results. We also missed 4 net deployments during mooring retrieval; larval concentration data were not interpolated for this period. Since the volume filtered by each net was generally large (mean $\pm \mathrm{SD}=1232 \pm$ $654 \mathrm{~m}^{-3}$ ) and the observed currents were strong (mean 
$=37.22 \mathrm{~cm} \mathrm{~s}^{-1}$, only $11 \%$ of observations below $10 \mathrm{~cm}$ $\mathrm{s}^{-1}$ ), we assumed that all nets sampled effectively. Plankton sampling was not replicated, so variance in larval abundance was not calculated. Larval concentrations were expressed as larvae $1000 \mathrm{~m}^{-3}$.

In the laboratory, fishes were sorted, identified to the lowest taxonomic level possible, and up to 20 individuals of each non-flounder species were measured (standard length) from each sample. We defined 3 size classes of Atlantic croaker Micropogonias undulatus: $<9 \mathrm{~mm}, 9$ to $11 \mathrm{~mm}$ and >11 mm. Similarly, 3 size classes of Atlantic menhaden Brevoortia tyrannus were defined: <18.5 mm, 18.5 to $22 \mathrm{~mm}$, and > $22 \mathrm{~mm}$. Sizes were chosen to segregate the smallest and largest $25 \%$ of the larvae. The developmental stage of flounders was determined following Goto et al. (1989). Most fishes collected were transforming from larvae to juveniles; for ease, they are referred to as larvae, but a more apt description would be transformation stage fishes (Fig. 2). The size division in Atlantic croaker and Atlantic menhaden did not demarcate any key ontogenetic events (e.g. completion of fin development, squamation), but provided a proxy for larval development (similar to the staging of flounder) based on the concept that size is a better proxy for ontogeny than age (Fuiman \& Higgs 1997).

Flux calculations. The flux of salt, suspended sediment, and larval fishes was calculated to evaluate
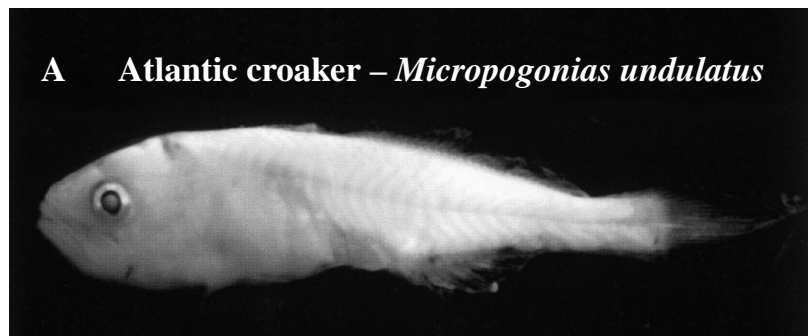

B Atlantic menhaden - Brevoortia tyrannus

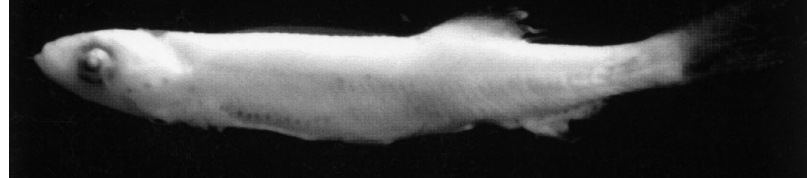

C Summer flounder - Paralichthys dentatus

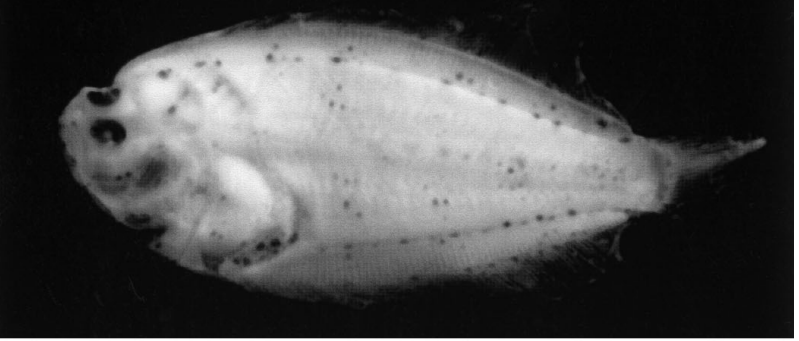

Fig. 2. Micropogonias undulatus (11 mm), Brevoortia tyrannus $(21 \mathrm{~mm})$ and Paralichthys dentatus stage G stage $(10 \mathrm{~mm})$ whether fishes move passively into an estuary (passively in residual bottom inflow or wind forced inflow), or in combination with tidal currents (passively due to physical processes in phase with tides or actively through selective tidal stream transport). Salt-flux and larval fish flux calculations were made directly from salinity measurements and larval fish concentrations. Suspended sediment flux calculations were made using ADCP backscatter as a proxy (Holdaway et al. 1999, Chant \& Stoner 2001). Relative backscatter from the ADCP was processed by Jenkins (2002) to account for transmission loss from radial spreading and sound attenuation following Deines (1999). Jenkins (2002) found little correlation between ADCP backscatter and the concentration of zooplankton in the water column and concluded that the ADCP backscatter could be used as a depth-resolved measure of total suspended particles in the water column.

Flux calculations followed Churchill et al. (1999). Net total flux $(T)$ was calculated with concentration, $C$ (salinity, suspended sediment, or larval concentrations) and along estuary flow $(U)$ :

$$
T=\int U C \mathrm{~d} t
$$

Net total flux was then decomposed into that due to mean flow (net advective flux, $T_{\mathrm{A}}$ ) and that resulting from the covariation between concentration and flow (net covariance flux, $T_{\mathrm{C}}$ ):

$$
\begin{gathered}
T=T_{\mathrm{A}}+T_{\mathrm{C}} \\
T_{\mathrm{A}}=\int \overline{U C} \mathrm{~d} t \\
T_{\mathrm{C}}=\int(U-\bar{U})(C-\bar{C}) \mathrm{d} t
\end{gathered}
$$

$\bar{U}$ and $\bar{C}$ are the mean along estuary flow and mean concentration over a given period. Flux calculations were made for each depth (i.e. $\bar{C}$ and $\bar{U}$ calculated for each depth), and integration intervals were over each of 3 nighttime tidal cycles, 1 during strong northwest winds, 1 during the relaxation in wind stress, and 1 during weak southerly winds. Nighttime cycles were chosen because several studies have indicated that many species exhibit selective tidal stream transport only at night (see Forward \& Tankersley 2001) and to limit the effect on the analyses of any day/night differences in the effectiveness of the sampling gear.

Salt, suspended sediment, and larval fish fluxes were further segragated into 3 categories to evaluate the role of wind-forcing, residual bottom inflow, and tidal forcing in affecting larval ingress. Wind-driven flux was defined as the net advective flux $\left(T_{\mathrm{A}}\right)$ at all 3 depths during the second nightime tidal cycle; this tidal cycle corresponded to the relaxation in wind forcing when baroclinic inflow into the estuary was expected (Valle-Levinson et al. 2001). Residual bottom 
flux was defined as the net advective flux $\left(T_{\mathrm{A}}\right)$ at the near-bottom depth during all 3 tidal cycles. Tidally driven flux was defined as the net covariance flux $\left(T_{\mathrm{C}}\right)$ at all depths during all 3 tidal cycles. These 3 categories are not inclusive of all the flux calculations and overlap to some degree, but their magnitude provides an estimate of the relative importance of the 3 potential mechanisms of larval ingress.

Examination of physical factors that could affect net covariance flux of larvae. Tidal patterns in larval concentrations and net covariance flux could result from active, behavioral processes (e.g. selective tidal stream transport) or passive, physical processes that co-vary with tidal flows (e.g. water mass, vertical mixing, buoyancy). Behavioral processes cannot be evaluated with the data collected, but the role of physical processes in affecting tidal patterns in larval distributions can be evaluated. If the role of physical processes can be rejected, then behavioral processes are indicated as the causative factor for covariation between larval abundance and the tidal flow field, thereby supporting selective tidal stream transport as a hypothesis for the ingress of larvae into Chesapeake Bay.

Water mass effects: Water masses were defined based on discrete groupings in temperature and salinity. Flux calculations were then made as above, but for each water mass during the 3 tidal cycles. As several water masses moved past the station during the study, net water mass specific fluxes were not calculated with integration as presented in Churchill et al. (1999). Rather, net water mass specific fluxes were estimated by summing flux $(U C)$ over all the samples $(j)$ that were collected when a given water mass (WMi) was sampled during the 3 nighttime tidal cycles. Calculations were made for salt, suspended sediment and larvae. Net total flux for water mass $i$ (WMi) was estimated from concentrations and observed flow when water mass $i$ was present.

$$
T_{W M i}=\sum_{j} U_{j W M i} C_{j W M i}
$$

Net total flux for water mass $i$ was decomposed into net advective flux for water mass $i$ and net covariance flux for water mass $i$ in a manner analogous to the calculations above.

$$
\begin{gathered}
T_{W M i} \approx T_{\mathrm{A} W M i}+T_{\mathrm{C} W M i} \\
T_{\mathrm{A} W M i} \approx \bar{U}_{W M i} \bar{C}_{W M i} \\
T_{\mathrm{C} W M i} \approx \sum_{j}\left(U_{j W M i}-\bar{U}_{W M i}\right)\left(C_{j W M i}-\bar{C}_{W M i}\right)
\end{gathered}
$$

An increased importance of the net advective flux term of water mass specific flux would indicate that water mass distributions varied in phase with the tide, and water mass specific larval distributions (a passive process) contributed to the net covariance flux.
Water column density: Tidal patterns in larval concentrations may reflect passive responses to water column buoyancy. Summer flounder, Atlantic menhaden and Atlantic croaker larvae are negatively buoyant (Hoss et al. 1989, Govoni \& Hoss 2001, Hare et al. in press). If water column density varies in phase with tides, then it could passively cause net covariance flux of larvae (e.g. larvae on the bottom rising into the water column as a denser water mass moves over, or larvae being higher in the water column in a denser water mass and lower in the water column in a lighter water mass). Assuming constant larval buoyancy, increases in water column density should be positively correlated with net covariance flux. Correlation coefficients were calculated between covariance flux of larvae observed at time $t$ [i.e. $\left.\left(U_{t}-\bar{U}\right)\left(C_{t}-\bar{C}\right)\right]$ and water density observed at time $t$ at each depth during each tidal cycle. Correlations were calculated for each species and stage. Water density was averaged from the bottom to the depth of collection.

Vertical mixing: Tidal patterns in larval concentrations may reflect passive responses to vertical mixing. Summer flounder, Atlantic menhaden and Atlantic croaker larvae are negatively buoyant (Hoss et al. 1989, Govoni \& Hoss 2001, Hare et al. in press) and may occur in the water column during periods of mixing. Vertical mixing was not measured, but inferred from the Richardson number (Ri), which is the ratio of the stabilizing effects of stratification and the destabilizing effects of vertical shear in currents. A low $\mathrm{Ri}(<0.25)$ equates to large potential for vertical mixing, and a high $\mathrm{Ri}(>0.25)$ to limited potential for vertical mixing (Fortier \& Leggett 1983, Dyer 1997, Reiss et al. 2002). If vertical mixing leads to covariation between larval concentration and flow, then covariance flux $\left[\left(U_{t}-\bar{U}\right)\left(C_{t}-\bar{C}\right)\right]$ should be higher with low Ri $(<0.25)$ and lower with high Ri $(>0.25)$. Covariance fluxes were compared between observations with low and high Ri for each depth during each tidal cycle. Comparisons were made for each species and stage. If any Ri were $>0.25$ below the depth of collection, then all were classified as high; if no Ri were $>0.25$ below the depth of collection, then all were classified as low.

\section{RESULTS}

\section{Physical variables}

Tidal and event scale variability were evident in both the circulation and water properties during the study (Fig. 3). A strong NW wind event was underway at the beginning of sampling, with speeds in excess of $10 \mathrm{~m}$ $\mathrm{s}^{-1}$. After approximately $15 \mathrm{~h}$, winds subsided and were generally from the south and $<5 \mathrm{~m} \mathrm{~s}^{-1}$. Flow was initially ebb-dominated with a strengthening in flood tide during the subsiding of the NW winds. Ebb and 


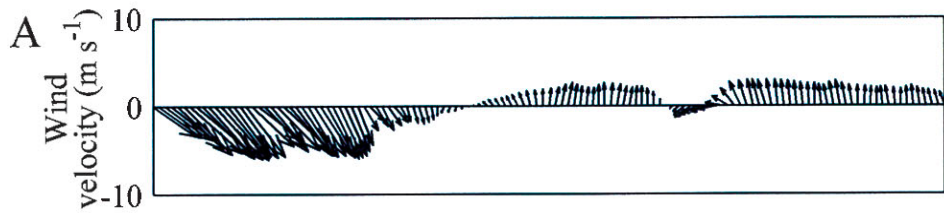

B
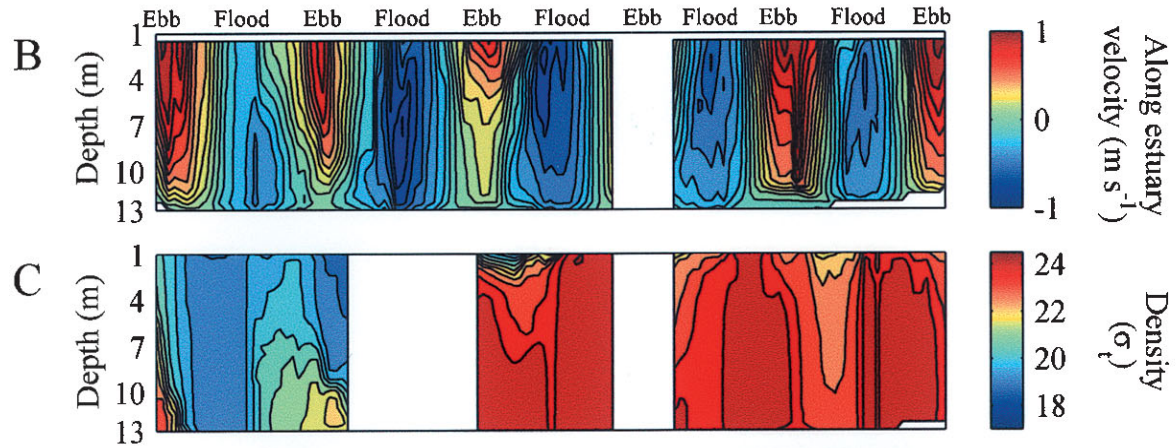

$\mathrm{D}$
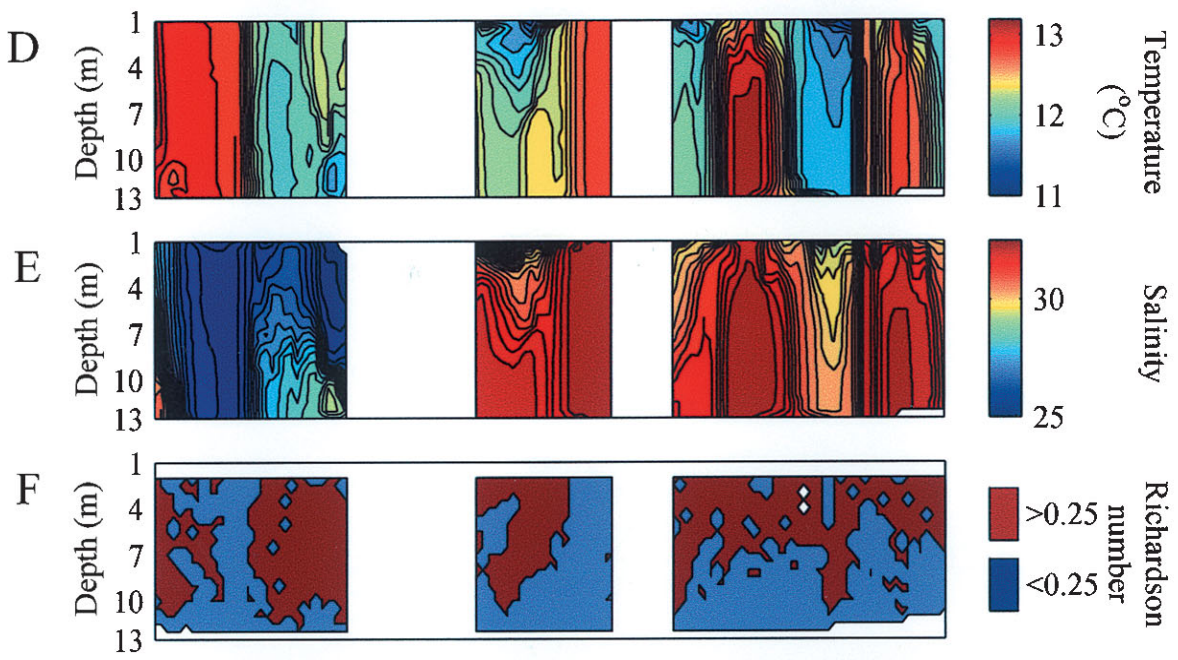

Fig. 3. Time series of physical variables measured in North Channel of Chesapeake Bay from 16 to 19 November 1999 during periods of ebb and flood tide. Data collected at anchor station in mouth of Chesapeake Bay (Fig. 1). CTD casts were made every 30 min and an ADCP deployed on a raft was sampled continuously. First period in $(\mathrm{C})$ to $(\mathrm{F})$ with no data corresponds to CTD malfunction, second period to leaving anchor station to retrieve nearby current meter mooring. $x$-axis: decimal day in GMT (e.g. 12:00 h GMT on 17 November $=17.5$ )

flood tides were approximately equal later in the time series. Water density and salinity were lower during the NW wind event and higher during the period of south wind. Water density was also lower during the last half of ebb and the first half of flood tide, and higher during the last half of flood and first half of ebb tide. Temperature and salinity exhibited similar tidal variability, with lower temperatures and salinities during the last half of ebb and the first half flood tide and higher temperatures and salinities during the last half of flood and the first half of ebb tide.

Richardson numbers were generally low $(<0.25)$ near the bottom and near the surface. High Ri occurred throughout the time series, but the width of these high Ri layers varied considerably and little tidal pattern was evident. In general, there were only a few occasions on which there was a potential for mixing throughout the water column.

Suspended sediment, as estimated by ADCP acoustic backscatter, was highest near the bottom and was higher in the water column during maximum ebb and flood tides. ADCP backscatter was also higher near the surface earlier in the time series, but it was not clear whether these high values represent sediment or bubbles mixed into the water through the high winds. 
Based on temperature and salinity, 3 water masses were defined (Fig.44). Water Mass 1 occurred early during the NW wind event and was relatively warm and fresh. Water Mass 2 occurred later during the NW wind event and was relatively cool and fresh. The transition between Water Masses 1 and 2 was abrupt. Both these water masses probably originated upstream in Chesapeake Bay and were moving downstream due to wind forcing. When the wind switched from the NW to the south, Water Mass 3 was encountered. This water mass was saltier, but spanned a wide range of temperature. Water Mass 3 was subdivided into 3 sub-masses (Fig. 4). Water Masses 3A and B occurred during the latter half of ebb and the first half of flood tide, Water Mass 3C during the latter half of flood and the first half of ebb tide. Water Mass 3 probably represented a mixture of oceanic and estuarine waters, with Water Masses 3A and B being more estuarine and Water Mass 3C more oceanic.
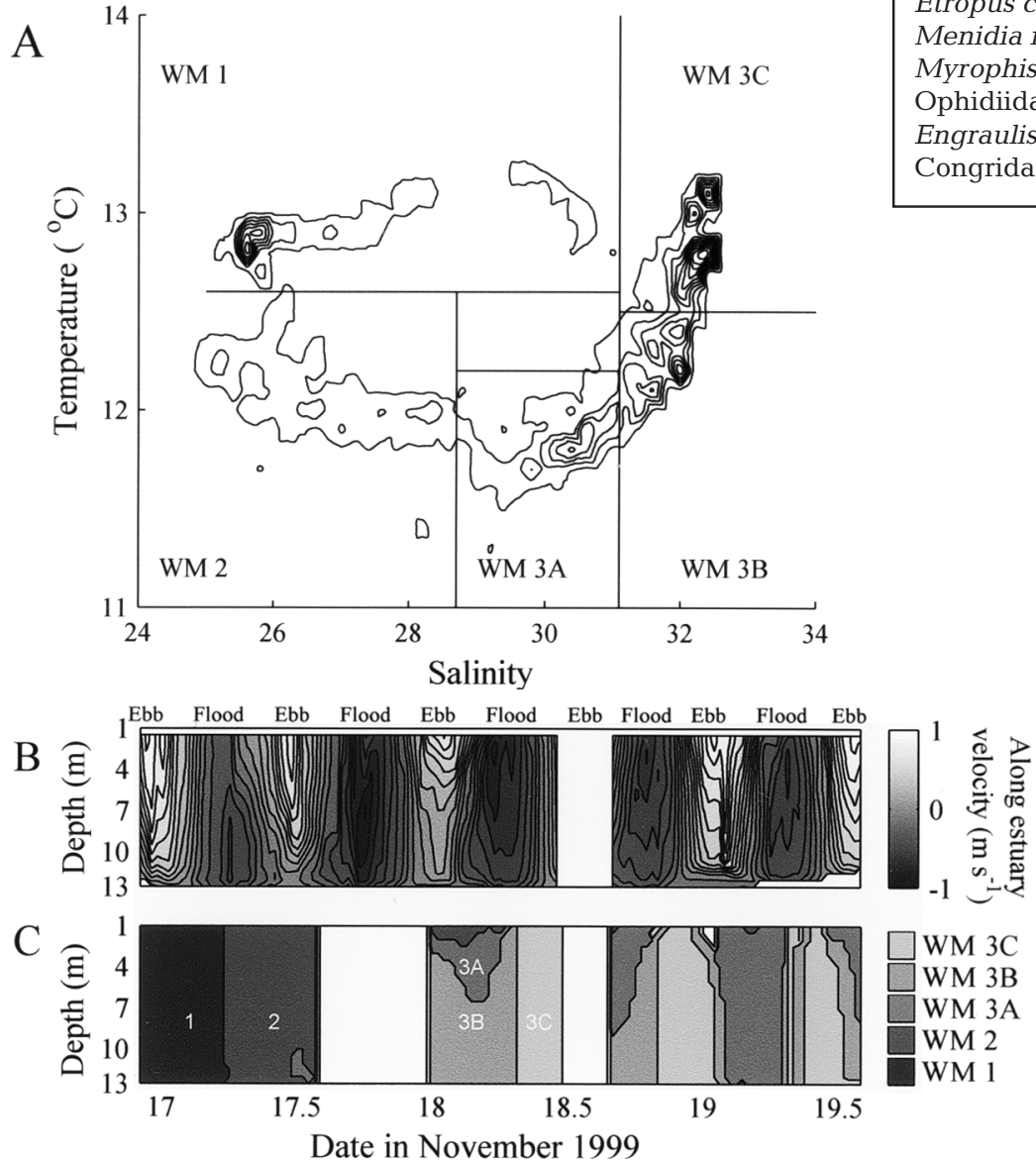

Fig. 4. (A) Contour plot of the frequency of temperature-salinity observations. Minimum contour is 5 observations and the contour interval is 10 observations. Three water masses were defined and 1 water mass was further segregated into 3 sub-water masses (WM1, WM2 WM3A, WM3B, WM3C). (B) Time series of along-estuary flow for reference (from Fig. 3). Periods of ebb and flood tide are identified. (C) Time series of classification of water mass occurrence. $x$-axis: decimal day
Table 1. Mean concentration of fishes caught in channel nets at mouth of Chesapeake Bay during November 1999

\begin{tabular}{|c|c|c|c|c|}
\hline \multirow[t]{2}{*}{ Taxon } & \multicolumn{4}{|c|}{ Mean concentration (ind. $1000 \mathrm{~m}^{-3}$ ) } \\
\hline & Total & Surface & Mid & Deep \\
\hline Micropogonias undulatus & 57.37 & 13.29 & 56.27 & 101.33 \\
\hline Paralichthys dentatus & 43.43 & 21.43 & 40.61 & 66.61 \\
\hline Brevoortia tyrannus & 7.04 & 1.54 & 4.73 & 13.71 \\
\hline Gobiidae & 1.29 & 0.86 & 1.75 & 1.47 \\
\hline Anchoa mitchilli & 0.72 & 0.26 & 0.57 & 1.26 \\
\hline $\begin{array}{l}\text { Myrophis punctatus } \\
\text { (leptocephalus) }\end{array}$ & 0.58 & 0.40 & 0.75 & 0.67 \\
\hline Blenniidae & 0.35 & 0.45 & 0.33 & 0.26 \\
\hline Syngnathus sp. & 0.31 & 0.27 & 0.54 & 0.21 \\
\hline Anchoa sp. & 0.10 & 0.02 & 0.14 & 0.16 \\
\hline Urophycis sp. & 0.07 & 0.03 & 0.04 & 0.14 \\
\hline Citharichthys spp. & 0.05 & 0.05 & 0.02 & 0.08 \\
\hline Hipocampus sp. & 0.05 & 0.06 & 0.08 & 0.01 \\
\hline Gobiosoma bosci & 0.04 & 0.01 & 0.00 & 0.09 \\
\hline Scopthalmus aquosus & 0.03 & 0.05 & 0.04 & 0.01 \\
\hline Symphurus spp. & 0.03 & 0.01 & 0.00 & 0.07 \\
\hline Elops saurus & 0.02 & 0.01 & 0.02 & 0.02 \\
\hline Etropus crossotus & 0.01 & 0.00 & 0.00 & 0.03 \\
\hline Menidia menidia & 0.01 & 0.03 & 0.00 & 0.00 \\
\hline Myrophis punctatus (elver) & 0.01 & 0.00 & 0.00 & 0.01 \\
\hline Ophidiidae & 0.00 & 0.00 & 0.01 & 0.00 \\
\hline Engraulis eurystole & 0.00 & 0.01 & 0.00 & 0.00 \\
\hline Congridae & 0.00 & 0.00 & 0.01 & 0.00 \\
\hline
\end{tabular}

\section{Larval fish collections}

We identified 22 taxa (Table 1 ), but 3 species dominated the catch numerically (96.8\%): Atlantic croaker Micropogonias undulatus, summer flounder Paralichthys dentatus and Atlantic menhaden Brevoortia tyrannus. Temporal and depth patterns were evident in the concentration of these 3 species (Fig.5). Fishes appeared to be more abundant and higher in the water column on flood tides. However, these patterns must be quantified before drawing conclusions regarding the processes shaping these distributions and the consequences for ingress into Chesapeake Bay.

\section{Flux estimates}

Salt and sediment

The total net salt flux during the 3 tidal cycles examined was typical of partially mixed estuaries (Fig. 6), being down estuary at the surface $(3.5 \mathrm{~m})$, 


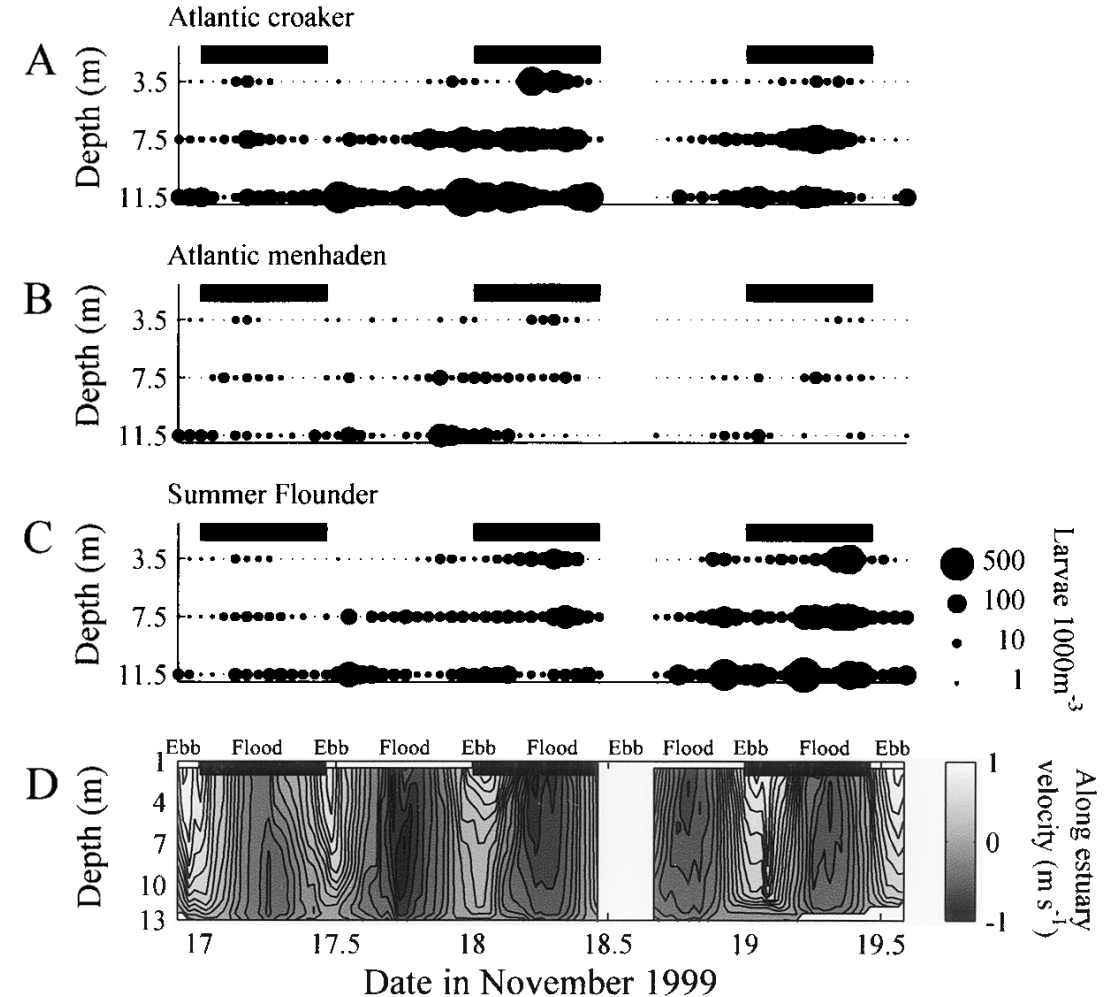

Fig. 5. Micropogonias undulatus, Brevoortia tyrannus, and Paralichthys dentatus. Temporal and vertical distribution of 3 most abundant taxa collected in the North Channel of Chesapeake Bay from 16 to 19 November 1999. Circle size indicates larval concentration (same scale for all species). Alongestuary velocity during ebb and flood tides (Fig. 3B) included for reference. Black bars: nighttime tidal cycles used in flux calculations; $X$-axis: decimal day pended sediment flux was composed primarily of the net advective flux component ( 96\%), and the net covariance flux component was small $(\sim 4 \%)$, and in the opposite direction to the net advective flux.

Variability in salt and sediment flux was evident among tidal cycles (Table 2). The first and third tidal cycle exhibited the general pattern of salt and sediment flux described above, but the second tidal cycle was characterized by up-estuary salt and sediment flux at all depths, consistent with an influx of water following the cessation of down-estuary winds (see Fig. 3).

\section{Larval fishes}

The net total flux of larval fishes was very different from those of salt and suspended sediment (Fig. 6). At the surface and middepth, the total net larval flux was up-estuary for all species/stages, and was dominated by the net covariance flux component. Net advective flux at the surface and mid-depth was either up- or down-estuary, and of a lower magnitude than net covariance flux (Atlantic menhaden $>22 \mathrm{~mm}$ at $7.5 \mathrm{~m}$ was the only exception). Total net larval flux near the bottom was up-estuary except for small $(<18.5 \mathrm{~mm})$ near zero at mid-depth $(7.5 \mathrm{~m})$, and up-estuary near the bottom $(11.5 \mathrm{~m})$. The total net salt flux was composed largely of the net advective flux component $(>99 \%)$, and the net covariance flux component was minimal $(<1 \%)$.

The net total flux of suspended sediment, as estimated by ADCP acoustic backscatter, was similar to that of the total net salt flux (Fig. 6), being down-estuary at the surface and up-estuary near the bottom. Net total sus- and medium (18.5 to $22 \mathrm{~mm}$ ) sized Atlantic menhaden and E-stage summer flounder. For Atlantic croaker, Atlantic menhaden, and E stage summer flounder, net covariance flux near the bottom was down-estuary and net advective flux near the bottom was either up-estuary or down-estuary. For G, H, and I stage summer flounder, net covariance flux near the bottom was upestuary and of greater magnitude than the up-estuary net advective flux.

Table 2. Total net flow and flux of salt and suspended sediment (estimated by ADCP backscatter) as a function of depth and tidal cycle. Net advective flux, net covariance flux and net total flux estimates are shown. Positive values are down-estuary, negative values up-estuary. Timing of 3 tidal cycles analyzed is shown in Fig. 5

\begin{tabular}{|c|c|c|c|c|c|c|c|c|}
\hline \multirow{2}{*}{$\begin{array}{l}\text { Tidal } \\
\text { cycle }\end{array}$} & \multirow{2}{*}{$\begin{array}{l}\text { Depth } \\
\text { (m) }\end{array}$} & \multirow{2}{*}{$\begin{array}{c}\text { Flow }\left(10^{3} \mathrm{~m}\right) \\
\text { Total }\end{array}$} & \multicolumn{3}{|c|}{- Salt $\left(10^{5} \mathrm{~kg} \mathrm{~m}^{-2}\right)-$} & \multicolumn{3}{|c|}{- Sediment $\left(10^{6} \mathrm{db} \mathrm{m}^{-2}\right)$} \\
\hline & & & Advective & Covariance & Total & Advective & Covariance & Total \\
\hline \multirow[t]{3}{*}{1} & 3.5 & 7.3 & 1.9 & 0.0010 & 1.9 & 0.7 & -0.02 & 0.7 \\
\hline & 7.5 & 1.4 & 0.4 & -0.01 & 0.4 & 0.1 & 0.02 & 0.2 \\
\hline & 11.5 & -2.6 & -0.7 & -0.001 & -0.7 & -0.3 & 0.04 & -0.3 \\
\hline \multirow[t]{3}{*}{2} & 3.5 & -4.7 & -1.5 & -0.006 & -1.5 & -0.4 & -0.04 & -0.4 \\
\hline & 7.5 & -7.6 & -2.5 & 0.008 & -2.5 & -0.8 & -0.02 & -0.8 \\
\hline & 11.5 & -7.4 & -2.4 & 0.009 & -2.4 & -0.8 & 0.02 & -0.8 \\
\hline \multirow[t]{3}{*}{3} & 3.5 & 6.7 & 2.1 & -0.03 & 2.1 & 0.6 & 0.02 & 0.6 \\
\hline & 7.5 & 3.4 & 1.1 & -0.003 & 1.1 & 0.3 & 0.01 & 0.3 \\
\hline & 11.5 & -0.2 & -0.06 & 0.002 & -0.06 & -0.2 & 0.08 & 0.6 \\
\hline
\end{tabular}



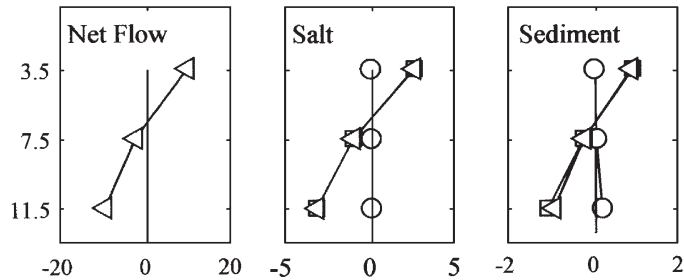

-O- covariance net flux $-\square$ advective net flux $\checkmark$ total net flux

Flux integrated over each of 3 tidal cycles and summed Net flow units $-10^{3} \mathrm{~m}$ Salt flux units $-10^{5} \mathrm{~kg} \mathrm{~m}^{-2}$ Sediment flux units $-10^{6} \mathrm{db} \mathrm{m}^{-2}$ Larval flux units - larvae $\mathrm{m}^{-2}$
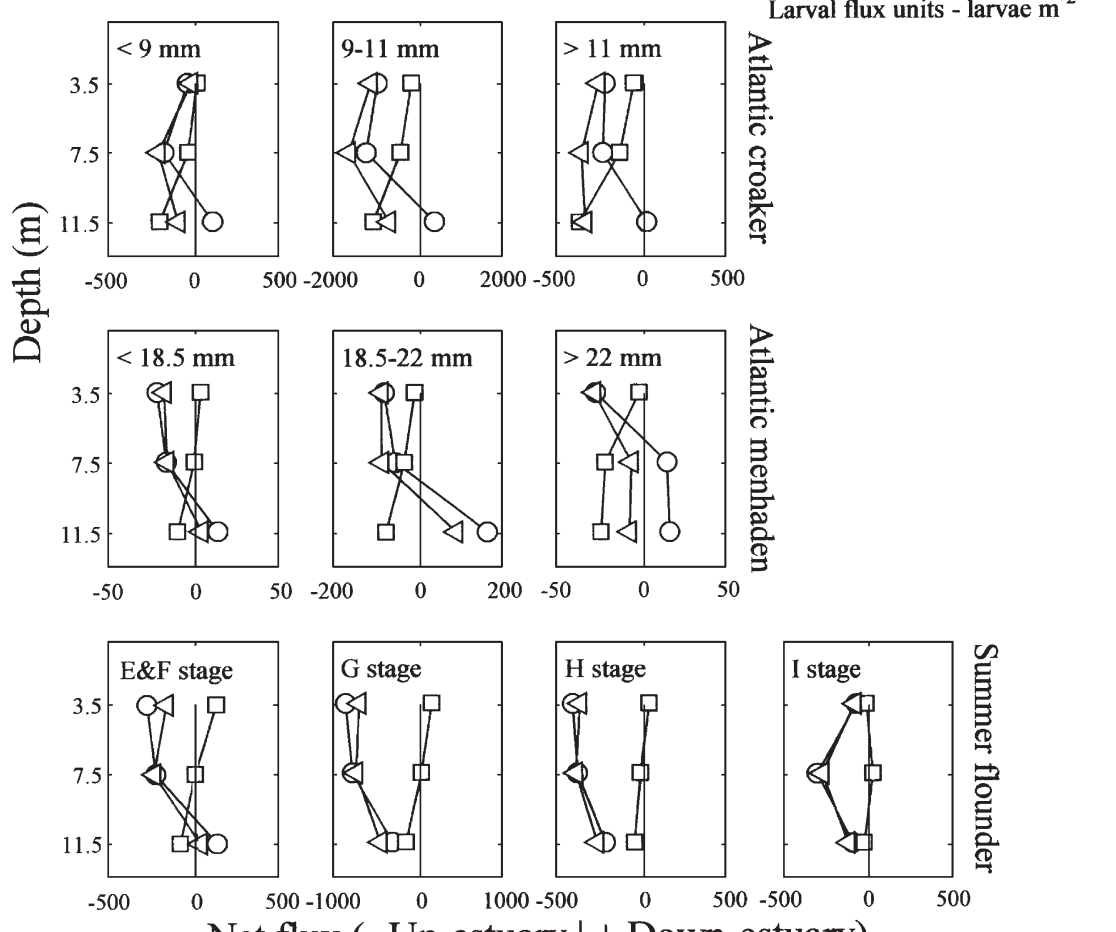

Net flux (- Up-estuary | + Down-estuary)

Fig. 6. Micropogonias undulatus, Brevoortia tyrannus, and Paralichthys dentatus. Summary of flux calculations for salt, suspended sediment, and different stages of Atlantic croaker, Atlantic menhaden and summer flounder. Net total flux, net advective flux and net covariance flux were summed over 3 tidal cycles shown in Fig. 5

The net advective flux of larvae during each tidal cycle (Tables $3,4 \& 5$ ) followed the pattern of the net advective flux of salt and sediment (Table 2). During tidal cycles 1 and 3, surface and mid-depth net advec- tive flux was down-estuary and bottom flux was up-estuary for all species and stages; during tidal cycle 2, net advective flux was up-estuary at all depths. Patterns in net covariance flux during each tidal cycle largely followed those described above for the 3 tidal cycles combined, however, a large amount of temporal variability was evident: upestuary net covariance flux of flounder was greater during the third tidal cycle, whereas up-estuary net covariance flux of Atlantic croaker and Atlantic menhaden was greater during the second tidal cycle.

The net covariance component of salt and sediment flux was small, since changes in salinity and sediment were not in phase with changes in water velocity (Fig. 3). For example, during the third tidal cycle, rapid decreases in salinity were observed during maximum ebb tide and rapid increases in salinity were observed during maximum flood tide. Thus during ebb (flood) tide, the flow component of the covariance equation $\left(U_{t}-\bar{U}\right)$ was positive (negative), but the salt and sediment component $\left(C_{t}-\bar{C}\right)$ were both negative and positive. Therefore $f\left(U_{t}-\bar{U}\right)\left(C_{t}-\right.$ $\bar{C})$ was small relative to the total flux. However, for larvae (e.g. summer flounder), above/below average concentrations were collected during flood/ebb tide, and thus $f\left(U_{t}-\bar{U}\right)\left(C_{t}-\bar{C}\right)$ was large relative to the total flux. Moreover, up-estuary flux of larvae occurred at the surface, despite net down estuary flow at the surface, because larvae occurred at the surface largely during flood tide and not at other times in the tidal cycle (Fig. 3).

Table 3. Micropogonias undulatus. Flux estimates as a function of length-class, depth and tidal cycle. Details as in Table 2 legend

\begin{tabular}{|c|c|c|c|c|c|c|c|c|c|c|}
\hline \multirow[t]{2}{*}{$\begin{array}{l}\text { Tidal } \\
\text { cycle }\end{array}$} & \multirow[t]{2}{*}{$\begin{array}{l}\text { Depth } \\
\text { (m) }\end{array}$} & & $<9 \mathrm{~mm}$ & & \multicolumn{3}{|c|}{$\begin{array}{l}\text { - No. of larvae } \mathrm{m}^{-2} \text { in length class } \\
\end{array}$} & \multirow{2}{*}{\multicolumn{2}{|c|}{$\begin{array}{l} \\
\text { tive } \quad 11 \mathrm{~mm} \\
\text { Covariance }\end{array}$}} & \multirow[b]{2}{*}{ Total } \\
\hline & & Advective & Covariance & Total & Advective & Covariance & Total & & & \\
\hline 1 & $\begin{array}{r}3.5 \\
7.5 \\
11.5\end{array}$ & $\begin{array}{r}13 \\
3 \\
-10\end{array}$ & $\begin{array}{r}-19 \\
-11 \\
4\end{array}$ & $\begin{array}{l}-7 \\
-8 \\
-6\end{array}$ & $\begin{array}{r}22 \\
18 \\
-73\end{array}$ & $\begin{array}{l}-29 \\
-93 \\
-28\end{array}$ & $\begin{array}{r}-7 \\
-75 \\
-100\end{array}$ & $\begin{array}{r}2 \\
4 \\
-17\end{array}$ & $\begin{array}{r}-1 \\
-23 \\
-14\end{array}$ & $\begin{array}{r}1 \\
-19 \\
-32\end{array}$ \\
\hline 2 & $\begin{array}{r}3.5 \\
7.5 \\
11.5\end{array}$ & $\begin{array}{r}-2 \\
-74 \\
-191\end{array}$ & $\begin{array}{r}-5 \\
-31 \\
68\end{array}$ & $\begin{array}{r}-7 \\
-105 \\
-123\end{array}$ & $\begin{array}{l}-214 \\
-704 \\
-981\end{array}$ & $\begin{array}{r}-847 \\
-450 \\
457\end{array}$ & $\begin{array}{r}-1061 \\
-1154 \\
-523\end{array}$ & $\begin{array}{r}-47 \\
-188 \\
-344\end{array}$ & $\begin{array}{r}-195 \\
-52 \\
71\end{array}$ & $\begin{array}{l}-242 \\
-240 \\
-273\end{array}$ \\
\hline 3 & $\begin{array}{r}3.5 \\
7.5 \\
11.5\end{array}$ & $\begin{array}{l}10 \\
37 \\
-1\end{array}$ & $\begin{array}{r}-12 \\
-132 \\
36\end{array}$ & $\begin{array}{r}-2 \\
-95 \\
35\end{array}$ & $\begin{array}{r}36 \\
265 \\
-10\end{array}$ & $\begin{array}{r}-78 \\
-678 \\
-60\end{array}$ & $\begin{array}{r}-42 \\
-414 \\
-69\end{array}$ & $\begin{array}{r}4 \\
59 \\
-2\end{array}$ & $\begin{array}{r}-12 \\
-149 \\
-25\end{array}$ & $\begin{array}{r}-9 \\
-90 \\
-27\end{array}$ \\
\hline
\end{tabular}


Table 4. Brevoortia tyrannus. Flux estimates as a function of length-class, depth, and tidal cycle. Details as in Table 2 legend

\begin{tabular}{|c|c|c|c|c|c|c|c|c|c|c|}
\hline \multirow[t]{2}{*}{$\begin{array}{l}\text { Tidal } \\
\text { cycle }\end{array}$} & \multirow[t]{2}{*}{$\begin{array}{l}\text { Depth } \\
(\mathrm{m})\end{array}$} & \multicolumn{3}{|c|}{$<18.5 \mathrm{~mm}$} & \multicolumn{3}{|c|}{$\begin{array}{l}\text { - No. of larvae } \mathrm{m}^{-2} \text { in length class } \\
\end{array}$} & \multirow{2}{*}{ Advective } & \multirow{2}{*}{$\begin{array}{l}>22 \mathrm{~mm} \\
\text { Covariance }\end{array}$} & \multirow[b]{2}{*}{ Total } \\
\hline & & Advective & Covariance & Total & Advective & Covariance & Total & & & \\
\hline 1 & $\begin{array}{r}3.5 \\
7.5 \\
11.5\end{array}$ & $\begin{array}{r}5 \\
3 \\
-9\end{array}$ & $\begin{array}{l}-7 \\
-9 \\
12\end{array}$ & $\begin{array}{r}-2 \\
-6 \\
2\end{array}$ & $\begin{array}{r}4 \\
3 \\
-11\end{array}$ & $\begin{array}{l}-5 \\
10 \\
32\end{array}$ & $\begin{array}{l}-1 \\
13 \\
20\end{array}$ & $\begin{array}{r}3 \\
0 \\
-1\end{array}$ & $\begin{array}{r}-4 \\
0 \\
0\end{array}$ & $\begin{array}{r}-1 \\
0 \\
-1\end{array}$ \\
\hline 2 & $\begin{array}{r}3.5 \\
7.5 \\
11.5\end{array}$ & $\begin{array}{r}-3 \\
-3 \\
0\end{array}$ & $\begin{array}{c}-11 \\
-5 \\
0\end{array}$ & $\begin{array}{r}-13 \\
-8 \\
0\end{array}$ & $\begin{array}{l}-16 \\
-54 \\
-63\end{array}$ & $\begin{array}{r}-60 \\
4 \\
83\end{array}$ & $\begin{array}{r}-76 \\
-51 \\
20\end{array}$ & $\begin{array}{r}-5 \\
-23 \\
-23\end{array}$ & $\begin{array}{r}-21 \\
18 \\
13\end{array}$ & $\begin{array}{r}-26 \\
-5 \\
-10\end{array}$ \\
\hline 3 & $\begin{array}{r}3.5 \\
7.5 \\
11.5\end{array}$ & $\begin{array}{l}2 \\
1 \\
0\end{array}$ & $\begin{array}{r}-4 \\
-2 \\
2\end{array}$ & $\begin{array}{r}-2 \\
-1 \\
2\end{array}$ & $\begin{array}{r}4 \\
20 \\
-1\end{array}$ & $\begin{array}{r}-13 \\
-67 \\
50\end{array}$ & $\begin{array}{r}-9 \\
-47 \\
49\end{array}$ & $\begin{array}{l}0 \\
1 \\
0\end{array}$ & $\begin{array}{r}-1 \\
-2 \\
4\end{array}$ & $\begin{array}{r}-1 \\
-1 \\
4\end{array}$ \\
\hline
\end{tabular}

Mechanisms of ingress

Separating the fluxes resulting from the 3 potential mechanisms of larval ingress demonstrated further that larval flux was different from salt flux and suspended sediment flux (Fig. 7). Salt and sediment fluxes were dominated by wind-driven flux and residual bottom flow flux; tidally driven flux of salt and sediment was minimal. In contrast, tidally driven flux was an important element of net larval flux, but the relative importance of the different mechanisms responsible for the overall up-estuary flux of larvae varied among species and size classes/stages (Fig. 7). Atlantic croaker ingress was apparently caused by a combination of wind forcing, residual bottom inflow, and tidalforcing. The importance of passive mechanisms (wind forcing and residual bottom inflow) decreased with increasing size and the importance of tidally driven flux increased with increasing size. For small Atlantic menhaden, tidally driven flux was primarily responsible for up-estuary net total flux. For larger size classes (18.5 to $22 \mathrm{~mm}$ and $>22 \mathrm{~mm}$ ), tidally driven flux was down-estuary, and wind-driven and residual bottom inflow were responsible for up-estuary movement of larvae. Tidally driven flux dominated the up-estuary flux of all stages of summer flounder, and the importance of wind-driven and residual bottom inflow decreased with increasing ontogenetic stage.

\section{Examination of physical factors that could affect net covariance flux of larvae}

\section{Water mass effects}

Net covariance flux dominated the up-estuary movement of larvae even when accounting for specific water masses (Fig.8). The net flow of 4 of the 5 water masses was down-estuary during the 3 tidal cycles. Water-mass specific net salt and sediment flux mir-

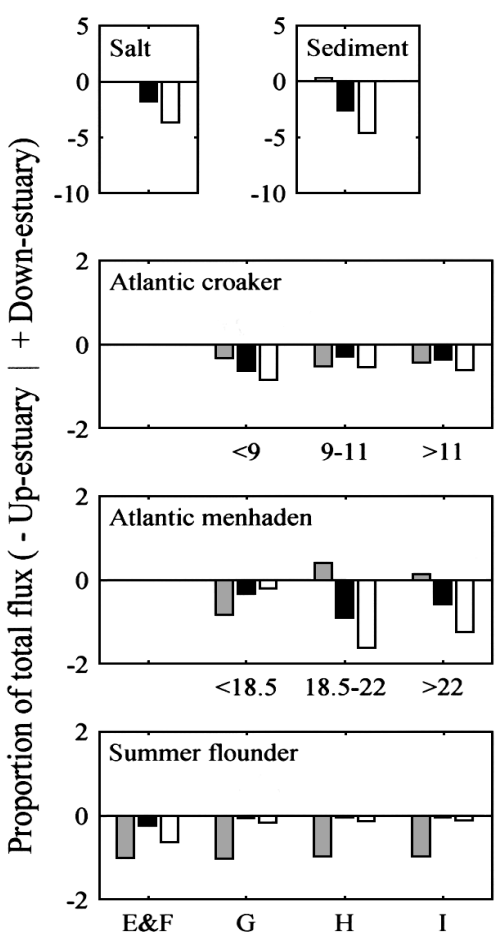

Length class (mm) / Ontogenetic stage

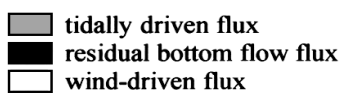

Fig. 7. Micropogonias undulatus, Brevoortia tyrannus, and Paralichthys dentatus. Summary of flux calculations for salt, suspended sediment, and different stages of Atlantic croaker, Atlantic menhaden and summer flounder, showing fluxes attributable to tidally driven flux, residual bottom flow flux and wind-driven flux. Tidally driven flux estimated as sum of net covariance terms $\left(T_{\mathrm{C}}\right)$ over the 3 depths and 3 tidal cycles. Residual bottom flow flux estimated as sum of net advective flux terms $\left(T_{\mathrm{A}}\right)$ for near-bottom depth $(11.5 \mathrm{~m})$ over 3 tidal cycles. Wind-driven flux estimated as sum of net advective flux terms $\left(T_{\mathrm{A}}\right)$ at all 3 depths during second tidal cycle (following relaxation of strong NW wind stress, see Fig. 3A). These 3 flux components are presented as proportion of total net flux, which is sum of net advective flux $\left(T_{\mathrm{A}}\right)$ and net covariance flux $\left(T_{\mathrm{C}}\right)$ terms over all 3 depths and the 3 tidal cycles 
Table 5. Paralichthys dentatus. Flux estimates as a function of stage, depth, and tidal cycle. Details as in Table 2 legend

\begin{tabular}{|c|c|c|c|c|c|c|c|c|c|c|c|c|c|}
\hline \multirow{3}{*}{$\begin{array}{l}\text { Tidal } \\
\text { cycle }\end{array}$} & \multirow{3}{*}{$\begin{array}{l}\text { Depth } \\
\text { (m) }\end{array}$} & \multirow{2}{*}{\multicolumn{3}{|c|}{ E \& F stage }} & \multicolumn{6}{|c|}{ No. of larvae $\mathrm{m}^{-2}$ in length class } & \multirow{3}{*}{ Advective } & \multirow{3}{*}{$\begin{array}{l}\text { - I stage } \\
\text { Covariance }\end{array}$} & \multirow{3}{*}{ Total } \\
\hline & & & & & & G stage & $\overline{-2}$ & $\overline{\mathrm{H}}$ & stage & 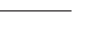 & & & \\
\hline & & Advective & Covariance & Total & Advective & Covariance & Total & Advective & Covariance & Total & & & \\
\hline \multirow[t]{3}{*}{1} & 3.5 & 0 & 0 & 0 & 9 & -9 & -1 & 3 & -4 & -1 & 3 & -3 & 0 \\
\hline & 7.5 & 0 & 0 & 0 & 6 & -25 & -19 & 3 & -12 & -10 & 1 & -4 & -3 \\
\hline & 11.5 & -2 & -1 & -3 & -25 & -57 & -83 & -7 & -19 & -26 & -6 & -6 & -12 \\
\hline \multirow[t]{3}{*}{2} & 3.5 & -41 & -42 & -83 & -60 & -197 & -257 & -40 & -148 & -188 & -16 & -59 & -75 \\
\hline & 7.5 & -132 & -69 & -202 & -134 & -57 & -191 & -79 & -74 & -154 & -26 & -29 & -55 \\
\hline & 11.5 & -88 & 77 & -11 & -104 & 39 & -65 & -34 & 4 & -31 & -18 & -10 & -28 \\
\hline \multirow[t]{3}{*}{3} & 3.5 & 155 & -249 & -94 & 216 & -642 & -426 & 79 & -255 & -176 & 2 & -9 & -6 \\
\hline & 7.5 & 121 & -172 & -51 & 172 & -692 & -520 & 66 & -293 & -227 & 54 & -270 & -216 \\
\hline & 11.5 & -9 & 42 & 33 & -13 & -295 & -298 & -5 & -204 & -209 & -2 & -79 & -81 \\
\hline
\end{tabular}

rored net flow. In contrast, net covariance flux of all 3 length classes of Atlantic croaker was up-estuary for all water masses and, in total, dominated water mass specific net flux estimates. Similar results were found for summer flounder and for Atlantic menhaden $<18.5$ $\mathrm{mm}$. Net covariance flux of 18.5 to $22 \mathrm{~mm}$ and $>22 \mathrm{~mm}$ Atlantic menhaden was strongly up-estuary in Water

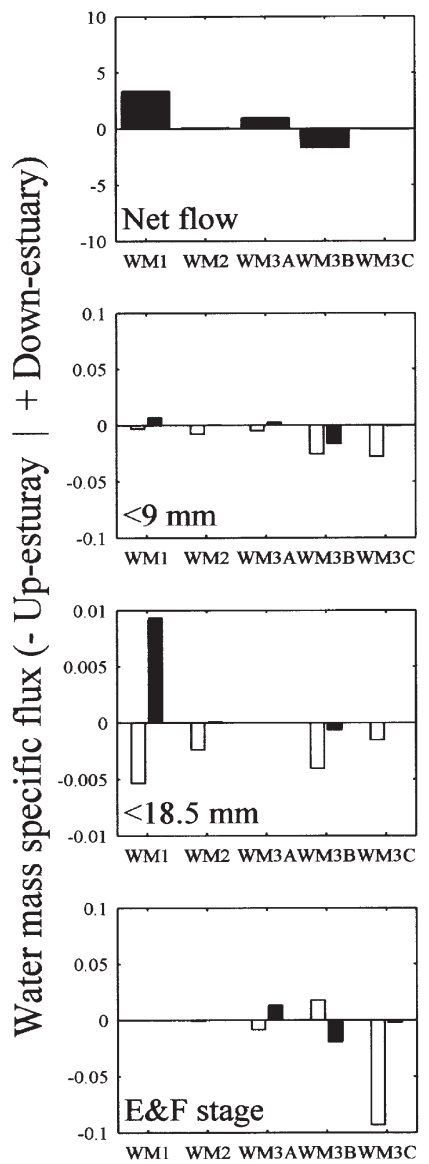

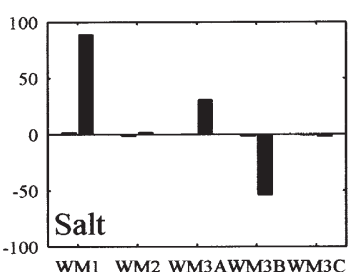
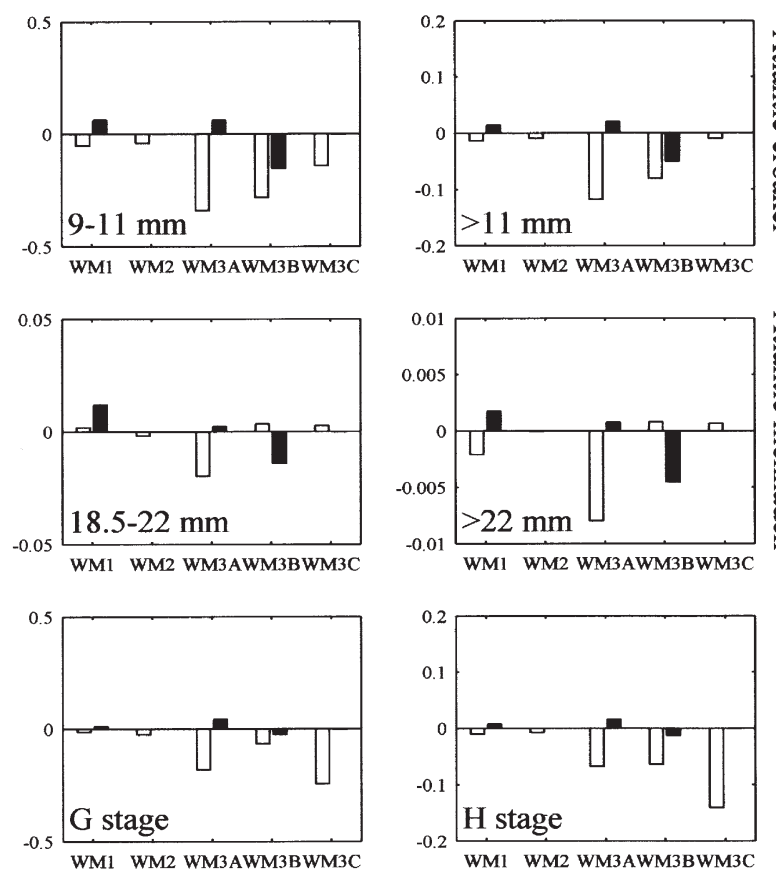

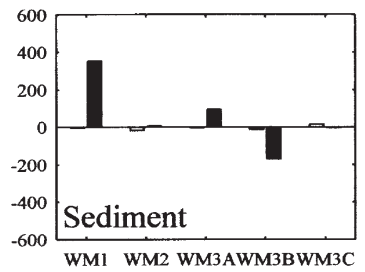

Mass 3A, contrary to net flow, net sediment flux, and net salt flux. However, net covariance flux was negligible or down-estuary for the 2 larger size classes of Atlantic menhaden in the other 4 water masses, indicating that water mass patterns in distribution may explain some of the net covariance flux in these 2 length classes.

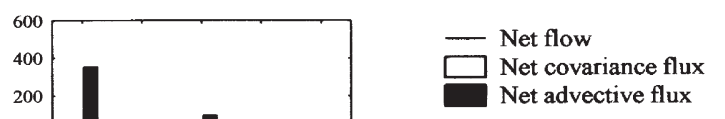

Flux summed for each water mass

Net flow units - m

Salt flux units $-\mathrm{kg} \mathrm{m}^{-2}$

Sediment flux units $-\mathrm{db} \mathrm{m}^{-2}$

Larval flux units - larvae $\mathrm{m}^{-2}$

Fig. 8. Micropogonias undulatus (panels in 2nd row), Brevoortia tyrannus (3rd row), and Paralichthys dentatus (last row). Summary of flux calculations made for specific water masses (see Fig. 4) during the 3 tidal cycles analyzed. Advective net water mass flux and covariance net water mass flux are shown for each water mass 

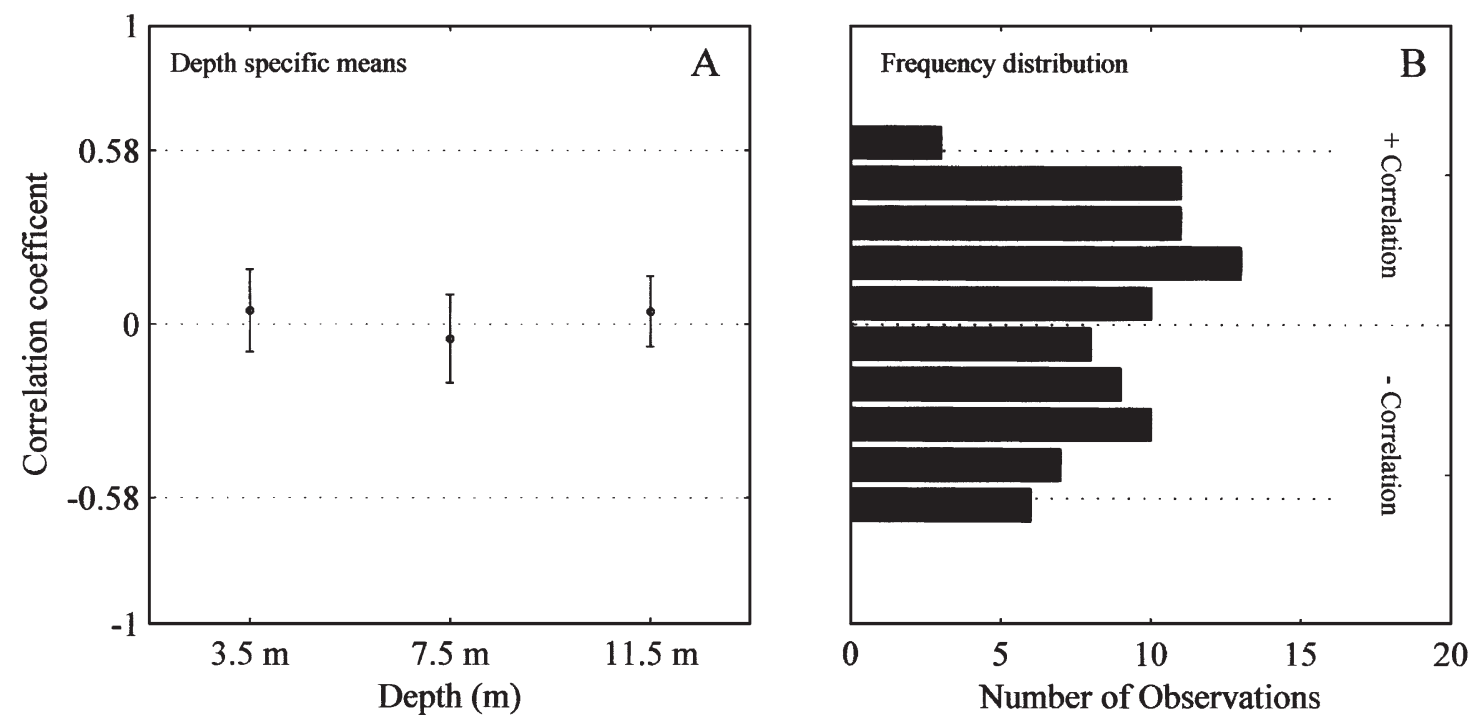

Fig. 9. Summary of correlation analyses between water column density and larval covariance flux. Correlations calculated for each species/stage at each depth during each tidal cycle. (A) Depth-specific mean $( \pm \mathrm{SD})$ correlation coefficients; (B) frequency distribution of all correlation coefficients. Significance level of $r= \pm 0.58$ is also shown. If larval buoyancy contributed to net covariance flux, then water column density should be positively correlated with net covariance flux

Buoyancy

The distribution of correlation coefficients between water column density and covariance flux ranged from 0.6 to -0.6 and no differences were apparent among depths (Fig.9). Taken as a whole, these results provide little support for the hypothesis that increases in water column density result in larvae moving higher into the water column and an increase in the net covariance flux.

\section{Vertical mixing}

Differences in the covariance fluxes were minimal between samples categorized as weak and strong mixing potential (i.e. high and low Richardson numbers respectively) (Fig. 10). Further, no differences in covariance fluxes between depths were apparent. In fact, covariance flux was typically greater under conditions with a low potential for mixing, as indicated by
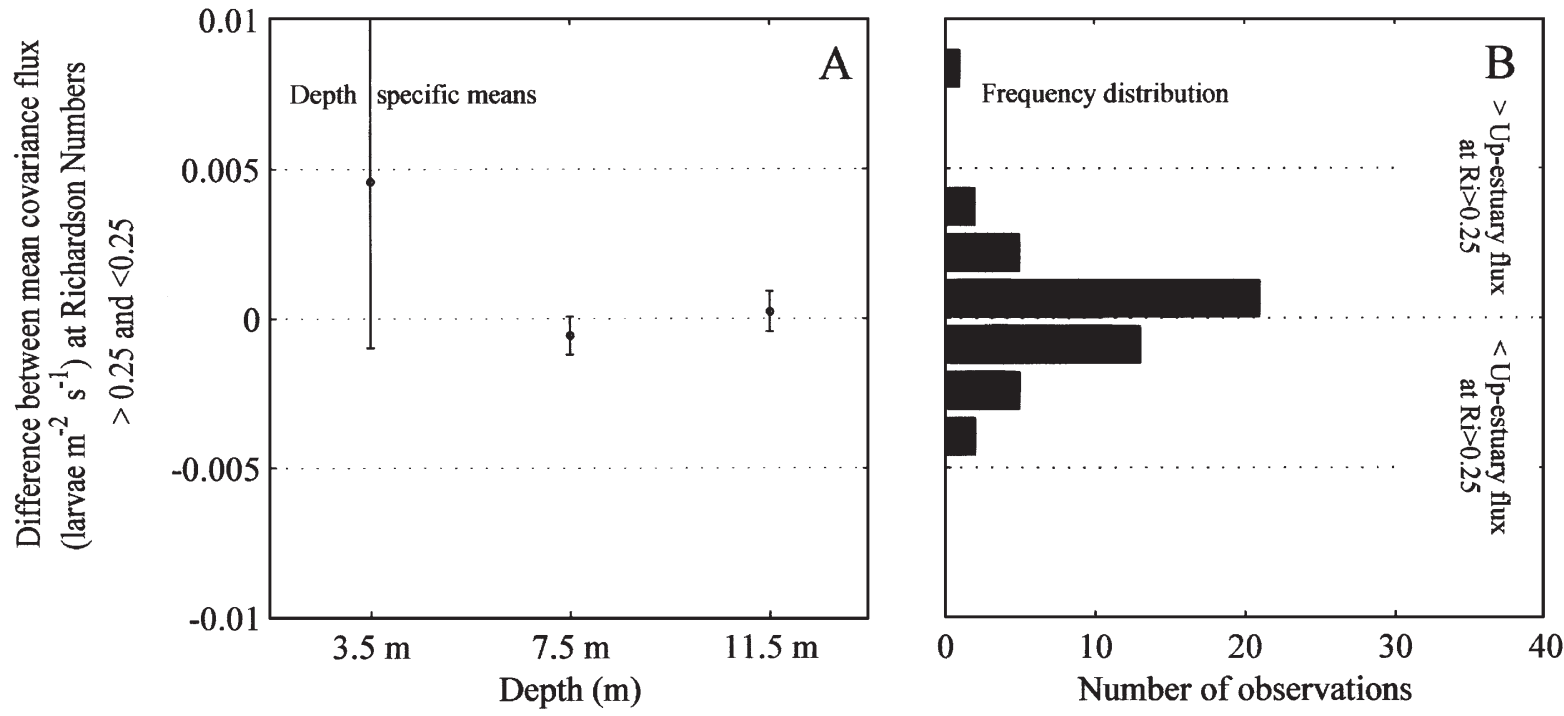

Fig. 10. Summary of difference in mean covariation flux for samples collected at high and low Richardson numbers. Differences calculated for each species/stage at each depth during each tidal cycle. (A) Depth-specific mean $( \pm$ SD) differences; (B) frequency distribution of all differences. High Richardson numbers $(\mathrm{Ri}>0.25)$ indicate limited potential for vertical mixing, low Richardson numbers $(\mathrm{Ri}<0.25)$ high potential. If vertical mixing contributed to covariance flux, then covariance fluxes should be higher (positive difference) when Richardson numbers are lower 
positive differences between net covariance flux of samples with high and low Richardson numbers. In total, these analyses indicate that vertical mixing plays at most a minor role in influencing the net covariance flux of larvae. However, it is important to note that vertical mixing was not measured, but inferred from Richardson numbers.

\section{DISCUSSION}

Although many studies have identified selective tidal stream transport as the mechanism of up-estuary transport, our results indicate a combined role of selective tidal stream transport, residual bottom inflow, and event scale, wind-driven flow (or responses thereto). Further, the importance of different ingress mechanisms varies among species and ontogenetic stages. Net covariance flux becomes more important as Atlantic croaker and summer flounder develop, but wind-driven flux and residual bottom inflow remain important for Atlantic croaker ingress, whereas covariance flux dominates for summer flounder ingress. In contrast, net covariance flux is important for ingress of smaller Atlantic menhaden, but results in downestuary movement of larger Atlantic menhaden; ingress of larger sizes of Atlantic menhaden occurs through wind-driven flux and residual bottom inflow. Additionally, the hypothesis that tidal patterns in larval distributions result from passive interactions with the physical environment is largely rejected. Taken as a whole, the results of this study indicate that larval vertical distributions are behaviorally determined, and that ingress results from behaviorally controlled vertical position co-varying with the tidally dominated flow field in combination with passive up-estuary movement during periods of net up-estuary movement of water (e.g. wind events, residual bottom inflow, spring tides).

An interesting ontogenetic 'interaction' was observed between residual bottom inflow and tidal currents (Fig. 6). For the younger/smaller stages of all 3 species, the covariation component of flux was downestuary in the bottom layer. These fishes were higher in the water column during flood tides resulting in upestuary transport in the surface and middle layers, then lower in the water column during ebb tides resulting in down-estuary transport in the bottom layer. As a result, the covariation flux of small larvae in the bottom layer was down-estuary, while the advective flux of small larvae in the bottom layer was up-estuary. As Atlantic croaker and summer flounder developed, the covariation component of flux in the bottom layer changed from down-estuary to up-estuary. One interpretation is that more-developed individuals are getting closer to the bottom on ebb tides, thereby limiting their down-estuary transport. By extension, as these species develop, their ability to perform selective tidal stream transport improves.

Hill (1991) demonstrated that even relatively small differences in vertical position in a vertically sheared flow can result in differences in net horizontal transport. Vertical shear was almost always present during this study (Fig. 3). Thus, small differences in vertical distribution, below the vertical scale of larval fish sampling, could impact horizontal transport. Measuring larval vertical distributions on the vertical scale of the current measurements would allow testing of our inference that larger and more developed Atlantic croaker and summer flounder larvae move closer to the bottom on ebb tides and limit their down-estuary transport.

Although we conclude that selective tidal stream transport contributes to larval ingress, our study does not address the underlying behavioral mechanisms. Forward et al. (1996) found that laboratory behavior of Atlantic menhaden larvae was different in oceanic water compared to estuarine water. DeVries et al. (1995) found that late stage Atlantic menhaden larvae change their behavior in response to changes in salinity. Burke et al. (1998) and Forward et al. (1998) demonstrated that late-stage larvae of several species have an entrained tidal rhythm in behavior. While the specific behavioral mechanisms responsible for selective tidal stream transport remain undefined, there is clear evidence that larvae have a complex suite of behaviors that could allow selective tidal stream transport.

The results of this study support and add to the conclusions of 4 recent studies. Joyeux (1999) concluded that Atlantic menhaden larvae entered Beaufort Inlet, North Carolina largely as a result of residual inflow, whereas spot, Atlantic croaker, summer flounder and pinfish entered primarily as a result of selective tidal stream transport. Churchill et al. (1999) decomposed flux into advective and covariation components based on larval collections made at Beaufort Inlet, North Carolina. They found that up-estuary flux was largely a result of the covariation component and that the relative importance of covariation flux was greatest in summer flounder. Rowe \& Epifanio (1994b) used an approach similar to that of Churchill et al. (1999) and found that the up-estuary transport of weakfish (Cynoscion regalis) larvae was associated with the covariation of larval concentration and flow. The covariation term was greatest higher in the water column and was greater for later ontogenetic stages. Similar to the Rowe \& Epifanio (1994b) and Churchill et al. (1999) studies, Jager \& Mulder (1999) used flux estimates to compare the ingress of flounder larvae Platichthys flesus to suspended sediment movement, and concluded that flounder enhance their passive up-estuary transport using selective tidal stream transport. Taken with 
the results of our study, this body of work supports the idea that multiple mechanisms effect larval ingress, and that the relative importance of mechanisms varies predictably among species and with development (see also Fortier \& Leggett 1983). Further, these studies indicate that a number of species move vertically in the water column at near tidal frequencies, and these movements affect up-estuary transport.

Prior studies and this study have also demonstrated temporal variability in the up-estuary flux of larvae (Tables 3, 4 \& 5). Wind-driven events causing the passive influx of larvae are, by their nature, temporally variable (Shaw et al. 1985, Valle-Levinson et al. 2001). In addition, net advective flux of larvae in the bottom layer (classified as residual bottom inflow) and net covariance flux of larvae also varied between tidal cycles. Similar temporal variability in the up-estuary flux of larvae was also observed in the studies of Rowe \& Epifanio (1994a,b), Churchill et al. (1999), and Jager \& Mulder (1999). This temporal variability is unexplained in terms of processes acting at ingress, and either results from unidentified processes operating at the opening to estuaries (e.g. lateral flow characteristics; Münchow et al. 1992, Valle-Levinson et al. 1998, 2001) or shelf processes supplying larvae to the proximity of estuarine openings (Hettler \& Hare 1998, Epifanio \& Garvine 2001).

Although our study had many novel aspects, there were limitations. Our small sample size for windevents was one. Future work should be conducted for a longer duration or in repetition to better resolve the importance of low frequency variation in up-estuary transport. Similarly, this study was conducted during neap tide conditions, and extension of the results to spring tide conditions is uncertain. We examined and rejected the role of physical factors causing tidal patterns in larval concentration, but were unable to test the hypothesis, in the field, that behavior is responsible for the observed larval vertical distributions. In future work examining behavioral aspects of selective tidal stream transport in the field should be emphasized (e.g. Leis \& Carson-Ewart 1999, Tolimeiri et al. 2000). Finally, the potential for vertical mixing was inferred from the Richardson number; actual measurements of vertical mixing were not made. Future research needs to examine the empirical relation between larval vertical distribution and vertical mixing in estuaries to directly evaluate the role of vertical mixing in affecting larval ingress.

Modeling could be used to further evaluate the relative importance of different ingress mechanisms (e.g. de Graaf et al. 2004). Particles could be given passive attributes of larvae (e.g. diurnal patterns in buoyancy, Hoss et al. 1989) and modeled distributions compared to the observed distributions presented here. Similarly, particles could be given active attributes of larvae (e.g. resisting vertical mixing on ebb tides) and modeled distributions again compared to observed distributions. Such a framework would allow the role of specific factors and processes to be evaluated in a 'controlled' environment and could lead to a clearer understanding of the role of biophysical processes in controlling larval distributions and ingress at estuarine openings.

Recent advances have been made in modeling larval transport on the continental shelf (e.g. Hare et al. 1999, Werner et al. 1999). These studies have assumed that if larvae arrive within a certain distance they are able to enter the estuary. This assumption is consistent with selective tidal stream transport or residual bottom inflow as mechanisms of ingress. However, the relative importance of wind forcing and the species and stage specific differences indicate that future modeling efforts would be improved with the explicit inclusion of ocean-estuary exchange in the larval transport models (e.g. Leuttich et al. 1999, Natunewicz et al. 2001) coupled with the models of behaviors that promote selective tidal stream transport and/or up-estuary transport in association with residual bottom inflow.

Determining the mechanisms of ingress remains an important goal for understanding the population dynamics of species that use estuaries as juvenile nurseries. For larvae that are capable of selective tidal stream transport, ingress is controlled by the processes that supply larvae to the tidal prism of the estuary; events may keep larvae from entering estuaries, but only for a short period of time. On the other hand, for larvae that depend on passive processes to enter estuaries (e.g. residual bottom inflow, wind forcing, spring tides), ingress will be controlled by the co-occurrence of the processes that supply larvae to the tidal prism of the estuary and the ingress forcing processes. These 2 different scenarios will create different patterns in larval ingress and potentially create differences in the population dynamics of species that use selective tidal stream transport (e.g. summer flounder) compared to species that depend more on passive up-estuary transport (e.g. Atlantic croaker and Atlantic menhaden).

Acknowledgements. We thank the officers and crew of the NOAA ship 'FERREL' for their hard work and dedication that allowed us to collect the data presented here. We also thank the scientific crew who participated in data collection. We acknowledge J. Govoni (NOAA/CCFHR), F. Hernandez (NOAA/CCFHR), and J. Churchill (WHOI) for reviewing earlier drafts of the manuscript. K. Jenkins corrected the backscatter ADCP data as part of his Masters research at Old Dominion University. Funding for this project was provided by the National Science Foundation through OCE 9876565 to C.J., S.T., A.V.-L., and J.A.H. Time on the NOAA ship 'FERREL' was provided by Virginia Sea Grant through NA56RG0489 to A.V.-L. 


\section{LITERATURE CITED}

Bergman MJ, van der Veer HW, Stam A, Zuidema D (1989) Transport mechanisms of larval plaice (Pleuronectes platessa L.) from the coastal zone in the Wadden Sea nursery area. Rapp P-V Réun Cons Int Explor Mer 191:43-49

Boehlert GW, Mundy BC (1994) Vertical and onshore-offshore distributional patterns of tuna larvae in relation to physical habitat features. Mar Ecol Prog Ser 107:1-13

Burke JS, Ueno M, Tanaka T, Walsh HJ and 5 others (1998) The influence of environmental factors on early life history patterns in flounder. J Sea Res 40:19-32

Chant RJ, Stoner AW (2001) Particle trapping in a stratified flood-dominated estuary. J Mar Res 59:29-51

Churchill JH, Forward RB, Luettich RA, Hensch JL, Hettler WF, Crowder LB, Blanton JO (1999) Circulation and larval transport within a tidally dominated estuary. Fish Oceanogr 8(Suppl 2):173-189

Cowen RK, Hare JA, Fahay MP (1993) Beyond hydrography: can physical processes explain larval fish assemblages within the Middle Atlantic Bight? Bull Mar Sci 53:567-587

Cronin TW (1982) Estuarine retention of larvae of the crab Rhithropanopeus harrisii. Estuar Coast Shelf Res 15: 207-220

de Graaf M, Jager Z, Vreugdenhill, Elorche M (2004) Numerical simulations of tidally cued vertical migrations of flatfish larvae in the North Sea. Estuar Coast Shelf Sci 59: 295-305

Deines KL (1999) Backscatter estimation using broadband acoustic Doppler current profilers. In: Anderson SP, Terray EA, White J, Wiliams AJ (eds) Proceedings of IEEE 6th working conference on current measurement. IEEE, San Diego, CA, p 249-253

DeVries MC, Forward RB, Hettler WF (1995) Behavioral response of larval Atlantic menhaden Brevoortia tyrannus (Latrobe) and spot Leiostomus xanthurus (Lacepede) to rates of salinity change. J Exp Mar Biol Ecol 185:93-108

Dittel AI, Epifanio CE (1990) Seasonal and tidal abundance of crab larvae in a tropical mangrove system, Gulf of Nicoya, Costa Rica. Mar Ecol Prog Ser 65:25-34

Dyer KR (1997) Estuaries: a physical introduction. Wiley, Chichester

Epifanio CE, Garvine RW (2001) Larval transport on the Atlantic continental shelf of North America: a review. Estuar Coast Shelf Sci 52:51-77

Fortier L, Leggett WC (1983) Vertical migrations and transport of larval fish in a partially mixed estuary. Can J Fish Aquat Sci 40:1543-1555

Fortier L, Leggett WC (1985) A drift study of larval fish survival. Mar Ecol Prog Ser 25:245-257

Forward RB, Tankersley RA (2001) Selective tidal-stream transport of marine animals. Oceanogr Mar Biol Annu Rev 39:305-353

Forward RB, Burke JS, Rittschof D, Welch JM (1996) Photoresponses of larval Atlantic menhaden (Brevoortia tyrannus) in offshore and estuarine waters: implications for transport. J Exp Mar Biol Ecol 199:123-135

Forward RB, Tankersley RA, Reinsel KA (1998) Selective tidal-stream transport of spot (Leiostomus xanthurus) and pinfish (Lagodon rhomboids, Linnaeus) larvae: contribution of circatidal rhythms in activity. J Exp Mar Biol Ecol 226:19-32

Fuiman LA, Higgs DM (1997) Ontogeny, growth, and the recruitment process. In: Chamber RC, Trippel E (eds) Early life history and recruitment in fish populations. Chapman \& Hall, London, p 225-249

Goto T, Sudo H, Tomiyama M, Tanaka M (1989) Settling period of larvae and juveniles of Japanese flounder Paralichthys olivaceus in Shijiki Bay, Hirado Island. Bull Jpn Soc Sci Fish 55:9-16

Govoni JJ, Hoss DE (2001) Comparison of the development and function of the swimbladder of Brevoortia tyrannus (Clupeidae) and Leiostomus xanthurus (Sciaenidae). Copeia 2001:430-442

Hare JA, Quinlan JA, Werner FE, Blanton BO, Govoni JJ, Forward RB, Settle LR, Hoss DE (1999) Larval transport during winter in the SABRE study area: results of a coupled vertical larval behavior - three-dimensional circulation model. Fish Oceanogr 8 (Suppl 2):57-76

Hare JA, Fahay MP, Cowen RK (2001) Springtime ichthyoplankton of the slope region off the north-eastern United States of America: larval assemblages, relation to hydrography and implications for larval transport. Fish Oceanogr 10:164-192

Hare JA, Walsh HJ, Wuenschel M (in press) Sinking rates of late-stage fish larvae: implications for larval ingress into estuarine nursery habitats. J Exp Mar Biol Ecol

Harrison W, Norcross JJ, Pore NA, Stanley EM (1967) Circulation of shelf waters off the Chesapeake Bight - surface and bottom drift of continental shelf waters between Cape Henlopen, Delaware and Cape Hatteras, North Carolina June 1963 to December 1964. Environmental Science Services Administration Professional Paper 3. US Department of Commerce, Washington, DC

Henri M, Dodson JJ, Powles H (1985) Spatial configuration of young herring (Clupea harengus harengus) larvae in the St Lawrence estuary: importance of biological and physical factors. Can J Fish Aquat Sci 42:91-104

Hettler WF, Hare JA (1998) Abundance and size of larval fishes outside the entrance to Beaufort Inlet, North Carolina. Estuaries 21:476-499

Hill AE (1991) Vertical migration in tidal currents. Mar Ecol Prog Ser 75:39-54

Holdaway GP, Thorne PD, Flatt D, Jones SE, Prandle D (1999) Comparison between ADCP and transmissometer measurements of suspended sediment concentration. Cont Shelf Res 19:421-441

Hoss DE, Checkley DM, Settle LR (1989) Diurnal buoyancy changes in larval Atlantic menhaden (Brevoortia tyrannus). Rapp P-V Réun Cons Int Explor Mer 191:105-111

Jager Z, Mulder HP (1999) Transport velocity of flounder larvae (Platichthys flesus L.) in the Dollard (Ems estuary). Estuar Coast Shelf Sci 49:327-346

Jenkins AK (2002) Vertical distributions of zooplankton at the mouth of Chesapeake Bay and calibration of backscatter from an Acoustic Doppler Current Profiler. Masters thesis. Old Dominion University, Norfolk, VA

Johnson DF, Hess KW (1990) Numerical simulations of blue crab larval dispersal and recruitment. Bull Mar Sci 46:195-213

Johnson DR (1995) Wind forced surface currents at the entrance to Chesapeake Bay: their effect on blue crab larval dispersion and post-larval recruitment. Bull Mar Sci 57: 726-738

Joyeux JC (1999) The abundance of fish larvae in estuaries: within-tide variability at inlet and immigration. Estuaries 22:889-904

Kincaid C, Pockalny RA, Huzzey LM (2003) Spatial and temporal variability in flow at the mouth of Narragansett Bay. J Geophys Res 108:3218-3235

Leis JM, Carson-Ewart BM (1999) In situ swimming and settlement behavior of larvae of an Indo-Pacific coral reef fish, the coral trout (Pisces, Serrandiae, Plectropomus leopardus). Mar Biol 134:51-64

Luettich RA, Hench JL, Fulcher CW, Werner FE, Blanton BO, 
Churchill JH (1999) Barotropic tidal and wind-driven larval transport in the vicinity of a barrier island inlet. Fish Oceanogr 8(Suppl 2):190-209

Münchow A, Garvine RW, Pfeiffer TF (1992) Subtidal currents from a shipboard acoustic Doppler current profiler in tidally dominated waters. Cont Shelf Res 12:499-515

Natunewicz CC, Epifanio CE, Garvine RW (2001) Transport of crab patches in the coastal ocean. Mar Ecol Prog Ser 222: 143-154

Norcross BL (1991) Estuarine recruitment mechanisms of larval Atlantic croakers. Trans Am Fish Soc 120:673-683

Olmi EJ (1995) Ingress of blue crab megalopae in the York River, Virginia, 1987-1989. Bull Mar Sci 57:753-780

Reiss CS, McConaugha JR (1999) Cross-frontal transport and distribution of ichthyoplankton associated with Chesapeake Bay plume dynamics. Cont Shelf Res 19:151-170

Reiss CS, Anis A, Taggart CT, Dower JF, Ruddick B (2002) Relationships among vertically structured in situ measures of turbulence, larval fish abundance and feeding success and copepods on Western Bank, Scotian Shelf. Fish Oceanogr 11:156-174

Roman MR, Boicourt WC (1999) Dispersion and recruitment of crab larvae in the Chesapeake Bay plume: physical and biological controls. Estuaries 22:563-574

Rowe PM, Epifanio CE (1994a) Tidal stream transport of weakfish larvae in Delaware Bay, USA. Mar Ecol Prog Ser 110:105-114

Rowe PM, Epifanio CE (1994b) Flux and transport of larval weakfish in Delaware Bay, USA. Mar Ecol Prog Ser 110: $115-120$

Editorial responsibility: Otto Kinne (Editor-in-Chief), Oldendorf/Luhe, Germany
Schultz ET, Lwiza KMM, Fencil MC, Martin JM (2003) Mechanisms promoting upriver transport of larvae of two species in the Hudson River estuary. Mar Ecol Prog Ser 251:263-277

Sclafani M, Taggart CT, Thompson KR (1993) Condition, buoyancy, and the distribution of larval fish: implications for vertical migration and retention. J Plankton Res 15: 413-435

Shaw RF, Wiseman WJ, Turner RE, Rouse LJ, Condrey RE (1985) Transport of larval gulf menhaden Brevoortia tyrannus in continental shelf waters of western Louisiana: a hypothesis. Trans Am Fish Soc 114:452-460

Tolimieri N, Jeffs A, Montgomery J (2000) Ambient reef sound as a navigational cue for the larvae of reef fish. Mar Ecol Prog Ser 207:219-224

Valle-Levinson A, Li C, Royer TC, Atkinson LP (1998) Flow patterns at the Chesapeake Bay entrance. Cont Shelf Res 18:1157-1177

Valle-Levinson A, Wong KC, Bosley KT (2001) Observations of the wind-induced exchange at the entrance to Chesapeake Bay. J Mar Res 59:391-416

Weinstein MP, Weiss SL, Hodson RG, Gerry LR (1980) Retention of three taxa of post-larval fishes in an intensively flushed tidal estuary, Cape Fear River, North Carolina. Fish Bull (Wash DC) 78:419-436

Werner FE, Blanton BO, Quinlan JA, Luettich RA (1999) Physical oceanography of the North Carolina continental shelf during the fall and winter seasons: implications for the transport of larval menhaden. Fish Oceanogr 8(Suppl 2): $7-21$

Submitted: December 12, 2004; Accepted: May 24, 2005

Proofs received from author(s): October 31, 2005 